\title{
Adoption of Cover Crops by U.S. Soybean Producers
}

\author{
Seungyub Lee ${ }^{\star}$ and Laura McCann \\ Department of Agricultural and Applied Economics, University of Missouri, Columbia, Missouri, USA \\ ${ }^{\star}$ Corresponding author. Email: slb66@mail.missouri.edu
}

\begin{abstract}
Using cover crops can be beneficial not only for soil health but also for the environment. However, relatively few farmers have adopted cover crops, so understanding the barriers to adoption is necessary. We used a probit model with data on 1,712 soybean producers from the 2012 USDA Agricultural Resource Management Survey to identify factors affecting adoption of cover crops. We found that more precipitation was positively correlated with adoption, as was more hired labor. Adoption was also positively correlated with crop diversification and no-till adoption, which may relate to equipment availability.
\end{abstract}

Keywords: Adoption; conservation; cover crops; water quality

JEL Classifications: Q55; Q25; Q52

\section{Introduction}

Agricultural nonpoint sources are the leading contributor to water pollution in the United States, but the problem can be reduced by adopting appropriate management practices (U.S. Environmental Protection Agency [EPA], 2005). Cover cropping is a conservation practice in which another crop is planted to cover the soil and protect it from erosion during the nongrowing season (U.S. Department of Agriculture, Natural Resources Conservation Service [USDA-NRCS], 2018). Planting cover crops can be a win-win solution because it can not only reduce nonpoint-source pollutants (Sharpley and Smith, 1991; Zhang et al., 2017) but also benefit crop yields (Conservation Technology Information Center [CTIC], 2017). Specifically, cover crops can be an effective practice for reducing soil erosion and nutrient loss, sequestering carbon, and improving soil health (Hoorman, 2009). It also can help stabilize yields (Bergtold et al., 2017). Even though use of cover crops is expanding (CTIC, 2017), the adoption rate is still low, less than 13\% of cropped farms in 2017 according to the Census of Agriculture (U.S. Department of Agriculture, National Agricultural Statistics Service [USDA-NASS], 2019). A deeper understanding of cover crop adoption would be beneficial not only for farmers but also for environmental quality.

Research has shown that time/labor costs, lack of available equipment, and climate conditions, like precipitation and growing season, affect the feasibility of cover crop use (Arbuckle and Roesch-McNally, 2015; Bergtold et al., 2017; CTIC, 2017; Midwest Cover Crops Council, 2015). The few studies on adoption of cover crops, however, have omitted consideration of climate variables. This may be caused by the limited geographic scope of most studies. The objective of this study was to identify the factors affecting adoption of cover crops using the 2012 USDA Agricultural Resource Management Survey (ARMS), which focused on soybean producers in 19 states. This data set enables us to examine factors that hinder or facilitate adoption and also 
allows us to evaluate the impact of climate conditions on adoption of cover crops, which, to our knowledge, has not been examined previously.

Probit regression results showed that the influences on cover crop adoption were related to labor and equipment challenges, as well as climate conditions. Additionally, using cover crops was positively correlated with adoption of other environmental practices, such as no-till or reducing fertilizer use, and is thus seen as a complement to these practices.

The next section provides some scientific background on cover crops as a best management practice. The conceptual model section reviews the literature on adoption of conservation practices and, more specifically, cover crops, to generate the hypotheses that will be tested. A description of the data and methods is followed by presentation of the results. The conclusion discusses the implications of the research and suggests some areas for future research.

\section{Background on cover crops}

Water quality issues caused by agricultural nonpoint sources are increasing (Sharpley and Smith, 1991; Zhang et al., 2017) and can be mitigated by the use of cover crops. Nitrogen (N) losses occur primarily through leaching, denitrification, and volatilization potentially contributing to groundwater pollution, eutrophication, hypoxia, and climate change (Cameron, Di, and Moir, 2013; Ribaudo et al., 2011). Nitrate $\left(\mathrm{NO}_{3}\right)$ is a toxic compound that can leach into groundwater. It is produced via mineralization and nitrification of existing organic $\mathrm{N}$ by microbes and microorganisms in soil (Johnson et al., 2005). Dinnes et al. (2002) and Castellano et al. (2012) argue that there are temporal differences between nitrate use by crops and soil nitrate production under U.S. midwestern conditions. Most nitrate production from soil occurs in spring, but the peak of crop nitrogen requirements occurs in summer (Dinnes et al., 2002). Thus, cover crops can mitigate nitrate leaching by taking up the available $\mathrm{N}$ during periods when crop utilization is low (Castellano et al., 2012; Strock, Porter, and Russelle, 2004; Tonitto, David, and Drinkwater, 2006). Reduced amounts of $\mathrm{NO}_{3}$ reduce gaseous losses, including nitrous oxide $\left(\mathrm{N}_{2} \mathrm{O}\right)$, a greenhouse gas (Davidson et al., 2000). These reductions of available nitrogen also can reduce $\mathrm{N}$ runoff.

Cover crops can reduce soil erosion. Laloy and Bielders (2010) found that there was less soil loss and runoff in fields using cover crops than in those left untilled postharvest. Phosphorus (P) typically moves to surface water in runoff with the potential to cause eutrophication, especially in freshwater systems (Carpenter, 2005). Runoff contains both soluble P and eroded soil particles, which have a high $P$ content (Devlin et al., 2002). Therefore, using cover crops can reduce runoff of total P (Langdale, Leonard, and Thomas, 1985; Yoo, Touchton, and Walker, 1988). Runoff is reduced because cover crops reduce rainfall energy on soils because of interception by their stalks and leaves, and they also increase infiltration capacity and water storage ability. For example, taprooted cover crops can penetrate soil and create pores that facilitate the infiltration of rainfall (Chen and Weil, 2010; Reeves, 1994). Cover crops can also increase infiltration by reducing crusting, or the surface sealing of soil. Therefore, cover crops can reduce nonpoint-source pollutants from agriculture.

A concern is that cover crops and weeds might compete with cash crops for nutrients, but Wittwer et al. (2017) found that using legume cover crops not only reduced weed pressure but also increased yields because of the additional $\mathrm{N}$ source from atmospheric nitrogen fixation. Nutrient competition by cover crops may inhibit weeds, as can waterborne components (leachates) from the decomposition of some cover crops, such as winter rye and black oats. This can be useful in soybean production because the crop itself is insensitive to winter rye leachates (Forcella, 2014; Midwest Cover Crops Council, 2015).

Soil organic matter or carbon is another important factor for productivity and, to farmers, one of the well-known benefits of using cover crops (CTIC, 2017; Kaspar and Singer, 2011; Myers and 
Watts, 2015). Mbuthia et al. (2015) conducted a long-term (31 year) cotton production study in Tennessee and found there was more total organic carbon under cover crop (legume) and no-till, as well as higher yields, than no cover crop and tilled fields.

In relation to climate change, cover crops may contribute to both mitigation and adaptation. Important benefits may include carbon sequestration, as well as enhanced water infiltration and reduced evaporation (Kaye and Quemada, 2017). Sequestration of carbon transfers carbon dioxide, $\mathrm{CO}_{2}$, from the atmosphere into the soil and is one way to increase soil organic matter. Using cover crops can increase carbon sequestration and may thus help mitigate climate change (Kaye and Quemada, 2017; Lal, 2004). Heavy rainfall events and drought could increase because of climate change (Kaye and Quemada, 2017; Lu et al., 2015). During spring storms, the ability of cover crops to reduce erosion and runoff by covering soil and to reduce nutrient loss by uptake of residual nutrients (Steenwerth and Belina, 2008; Strock, Porter, and Russelle, 2004) would be particularly helpful. In a drought, cover crops can help retain soil moisture because of the mulch provided by cover crop residues (Kaye and Quemada, 2017). Also, certain crops with taproots, like radish, can create soil pores, which increase infiltration, and also enable the roots of cash crops to penetrate deeper (Chen and Weil, 2011). However, farmers need to be careful with cover crop termination because of water use competition with cash crops (Alonso-Ayuso, Gabriel, and Quemada, 2014). Specifically, if termination of cover crops is delayed, ${ }^{1}$ they will deplete soil moisture, especially in some regions that have soils with limited water holding capacity, and thus negatively affect cash crop yields (Balkcom et al., 2016).

Even though there are many advantages to using cover crops, this practice is complex and farmers need to consider issues such as timing of planting and termination, as well as the additional time and labor costs (Ward et al., 2018). The first concern of farmers considering adoption of cover crops is successful establishment of cover crops to get the associated benefits. According to a cover crops survey (CTIC, 2017), 73\% of respondents planted cover crops after harvest. Regions with a short growing season have a short window to plant cover crops because cover crops that are not winter hardy, such as legumes, need at least 4 to 6 weeks to obtain full benefits (Midwest Cover Crops Council, 2015). Also, farmers prefer to plant cover crops before soybeans rather than before corn (Midwest Cover Crops Council, 2015). This may be because there is a possibility of reduced yields of corn because of later planting if cover crop termination is delayed (Wallace et al., 2017). Competition for water, as well as establishment and termination issues, shows that climate is important.

Additionally, trialing cover crops might be easier for farmers who have already adopted no-till because of their equipment. For example, farmers need planting equipment with the ability to handle residue, such as no-till drills or planters (Grisso, Holshouser, and Pitman, 2009; Mirsky et al., 2013).

In this section, we have focused on the scientific background related to cover crops, and in the next section we examine the literature on adoption in order to develop our conceptual model and testable hypotheses.

\section{Conceptual framework}

Farmers will adopt cover crops if their expected utility, subject to their preferences and constraints (e.g., time and climate), is maximized by doing so. Utility is a function of various factors including expected benefits and costs of adopting a practice versus not adopting. The factors affecting adoption can be divided into five categories: (1) demographic factors, (2) farm characteristics, (3) adoption of related management practices or technologies, (4) environmental attitudes,

\footnotetext{
${ }^{1}$ Generally, termination of cover crops is recommended 10 days to 2 weeks before planting cash crops (Midwest Cover Crops Council, 2015).
} 
and (5) climate. These categories and explanatory variables are based on the extensive literature related to adoption studies of technologies and best management practices.

Among demographic factors, age is considered to negatively affect adoption of new practices. Older farmers are less likely to change their practices because of a shorter planning horizon (McBride and Daberkow, 2003; Prokopy et al., 2008; Soule, Tegene, and Wiebe, 2000). In their review, Bergtold et al. (2017) highlight the fact that short-term versus long-term considerations are important for cover crop adoption decisions. For cover crops, we hypothesize that younger farmers will have a higher likelihood of adoption, because benefits are realized over a period of years. Education assumes a linkage between knowledge and adopting a practice and has had a positive effect on the likelihood of adoption (McBride and Greene, 2013; Rogers, 2003; Schimmelpfennig and Ebel, 2016; Weber and McCann, 2015). Bergtold et al. (2012) used an education variable in their study of cover crops in Alabama, but it was not significant. Nevertheless, we expect that farmers with a higher education level are more likely to adopt cover crops because of the complexity discussed in the previous section.

Off-farm employment could be a factor affecting the adoption decision. In the literature, off-farm employment has shown mixed results because it can increase financial capability (Schimmelpfennig and Ebel, 2016) and reduce time available to consider and adopt a new technology (McBride and Greene, 2013). Gedikoglu, McCann, and Artz (2011) explained that off-farm employment may have a positive impact on a capital-intensive practice but a negative effect on a labor-intensive one. In a cover crop study, Bergtold et al. (2012) used a dummy variable for off-farm income, but it was not significant. Concerns about complexity and time may outweigh concerns regarding out-of-pocket expenses (Midwest Cover Crops Council, 2015; Ward et al., 2018). Thus, we included operator's off-farm work days to capture the time constraint and expect that farmers who have more off-farm works days will be less likely to adopt this practice.

Farm characteristics also have been shown to affect adoption. Larger farm size is often associated with adoption. Larger farms may benefit from economies of scale if there are fixed costs associated with a practice. Also, farm size could be a proxy for profitability of the farms. In a cover crop study, Dunn et al. (2016) found farmers who have larger farms are more likely to plant more cover crops. On the other hand, according to CTIC (2017), one of the concerns about using cover crops for nonusers was time/labor costs that could become an issue for larger farms. So, we suspect that given the nature of the practice, while farmers operating larger farms will be more likely to adopt cover crops, the size effect will not be linear. Economies of scale with respect to equipment and information may benefit larger farms, but for very large farms, this effect is expected to level off. Additionally, the time constraint varies over the year; farmers plant and terminate cover crops when they are also planting and harvesting cash crops. Therefore, if farmers have more labor availability, it may enable them to more easily manage cover crops. However, labor costs are also one of the concerns farmers have about using cover crops (CTIC, 2017; Midwest Cover Crops Council, 2015). So, farmers with higher labor costs may be reluctant to adopt cover crops because of additional costs and labor management requirements. We include the number of hired laborers in the analysis and expect farmers who hire more workers to be more likely to use cover crops but that the relationship may be nonlinear. In addition, we included an interaction term between farm size and labor to capture potential interdependencies that may exist in farming systems, such as the higher labor requirements of systems that include animal production.

Land tenure determines whether farmers can make sustainable management plans and whether they would receive the future benefits from planting cover crops (McBride and Daberkow, 2003; Soule, Tegene, and Wiebe, 2000). In a cover crop adoption study, Bergtold et al. (2012) found farmers renting more area were less likely to use cover crops. In a survey, a farmer said that "farmers are not farming rented land like the ground that they own" and "renters are afraid to make long-term investments" (Midwest Cover Crops Council, 2015, p. 23). We therefore include the 
percentage of acres owned of the total operated acres (owned plus rented) and expect that farmers with more owned acres are more likely to adopt cover crops.

Production diversity on a farm may create synergies and thus be an indicator of adoption of cover crops. Farmers planting a variety of crops may have a lower barrier to trying cover crops because of their equipment infrastructure and experiences with multiple crops (Arbuckle and Roesch-McNally, 2015; Singer, Nusser, and Alf, 2007). For example, a particular planter or drill can handle different sizes or types of seeds. Thus, we included the number of field crops ${ }^{2}$ and expect farmers who planted more crops will be more likely to use the practice. Farmers with livestock could get additional benefits from cover crops (Arbuckle and RoeschMcNally, 2015; Singer, Nusser, and Alf, 2007). Farmers having livestock can receive short-term economic returns from planting cover crops because they could provide grazing or forage for livestock (Lazarus and Keller, 2018; Midwest Cover Crops Council, 2015). Specifically, we included a variable for having cattle and calves on their farm and expect those farmers to be more likely to adopt cover crops.

Controlling weeds is one of the other potential benefits of using cover crops. Mirsky et al. (2013) found cover crop mulches can reduce weed germination by reducing sunlight and physical contact between weed seeds and soil. Also, Myers and Watts (2015) found 28\% of respondents used cover crops for weed control. Thus, we included percentage of cropped land (including pasture) treated for weeds and expect that farmers who treated land for weeds will be more likely to plant cover crops.

Crop insurance might have either a positive or negative effect on adoption of cover crops. Kaye and Quemada (2017) argue that using cover crops can reduce risk from extreme weather conditions, such as severe storms and drought, and other studies show cover crops are beneficial for the risk-averse farmer (Lu et al., 2000; Sarrantonio and Gallandt, 2003). However, farmers who used cover crops had an issue with possibly losing eligibility for crop insurance because of a tight deadline for cover crop termination (Marzen and Ballard, 2016). So, risk-averse farmers in some areas may be reluctant to use cover crops. Thus, the effect of federal crop insurance is unclear based on the literature. In our model, we use a dummy variable for whether they enrolled in federal crop insurance to capture these potential effects.

Farmers may adopt soil conservation and nutrient management practices because of on- and off-farm benefits of the practices. One popular perceived benefit is reducing soil erosion, which can improve productivity (CTIC, 2016; Midwest Cover Crops Council, 2015) in addition to improving water quality. Thus, we included whether the soybean field on the operation was classified as highly erodible by the NRCS and expect this to be positively correlated with adoption.

Previous adoption of other management practices or technologies that improve water quality could be an indicator for adoption of cover crops (Schimmelpfennig and Ebel, 2016; Weber and McCann, 2015). Cover crops may improve water quality by reducing nutrient loss (Sharpley and Smith, 1991; Zhang et al., 2017). A study found farmers adopted practices for reducing fertilizer use if they believed the practices would improve water quality (Feather and Amacher, 1994). Farmers using soil tests can get detailed information about nutrients in their soil, which could help farmers use less fertilizer (Williamson, 2011) and reduce nutrient runoff. Soil tests also provide information on organic matter in the soil, so these farmers would have information on this soil health benefit of cover crops. Traditional tillage tends to increase soil erosion and reduce water infiltration, thus increasing water and nutrient runoff (Lal, Reicosky, and Hanson, 2007). Using conservation/no-tillage can reduce these problems and thus reduce water pollution (Gebhardt et al., 1985). We include adoption of reduced fertilizer use practices, soil testing, and conservation tillage/no-till in our model and hypothesize that farmers using these practices and technologies will be more likely to adopt cover crops.

${ }^{2}$ Field crops planted in addition to soybeans were corn, wheat, rice, peanuts, potatoes, and tobacco. 
The federal government has programs that encourage cover crop adoption. Conservation programs subsidize farmers to help them use environmentally friendly agricultural practices including cover crops. These programs include the Environmental Quality Incentives Program (EQIP) and the Conservation Stewardship Program (CSP). We expect farmers who have received funding from these programs will be more likely to adopt cover crops.

General pro-environmental attitudes could be a factor influencing adoption of cover crops and other environmental practices such as no-till. ARMS data do not include explicit questions on environmental attitudes that could be used to test this directly. One of the motivations to invest in solar energy use among early Austrian adopters was environmental awareness (Haas et al., 1999), and this has been confirmed more generally (e.g., Chen, 2014). Beckman and Xiarchos (2013) found farmers using conservation practices were more likely to be using renewable energy than the average farmer in California (USDA-NASS, 2011). Renewable energy systems, such as solar, are not associated with on-farm or off-farm benefits of cover crops or impacts on water quality. Thus, we included farmers' use of renewable energy systems (i.e., solar panels, wind turbines, geothermal, or small hydro ${ }^{3}$ ) as a proxy for general pro-environmental attitudes and hypothesize that farmers using them will be more likely to adopt cover crops. These systems are not related to crop production and, because they require a substantial investment, may be an indicator of relatively strong environmental preferences.

As mentioned previously, timing is a very important factor for successful establishment and termination of cover crops. The window for establishment or termination is largely dependent on climate variables, such as growing season and precipitation. As mentioned before, cover crops that are not winter hardy, like legumes, need at least 4 weeks for establishment (Midwest Cover Crops Council, 2015). If regions have longer growing seasons, farmers can have a longer window for seeding cover crops and higher probability of successful establishment. Also, precipitation is another important climate factor for termination. Farmers in dry regions without irrigation need to be careful about termination of cover crops because they can deplete the water available for cash crops. So, farmers in dry regions need to terminate cover crops earlier than in average or wet regions. Thus, we created variables for the 5 -year state average of growing season and of county-level precipitation, as detailed in the next section. We expect longer growing season and more precipitation to be associated with a higher likelihood of adoption of cover crops. We used the previous 5 years because the climate is changing (EPA, 2016) and recent events/weather are more likely to affect behavior than weather in the more distant past (Hertwig et al., 2004; Kaufmanna et al., 2017; Li, Johnson, and Zaval, 2011). In addition, we included an interaction term between growing season and precipitation to capture the fact that either one may be limiting for crop growth. In one model, we also included state dummy variables as controls instead of growing season to capture not only state specific climatic conditions but also policy and farming system differences.

Irrigation can ease the water constraint in drier areas. Farmers using irrigation may use cover crops to increase soil water availability (Bergtold et al., 2012) and reduce irrigation costs (Curell, 2012). In a cover crop adoption study, Bergtold et al. (2012) used conservation tillage, irrigation, and the total number of conservation practices, but only irrigation was significant, and more irrigation increased adoption.

To summarize, based on the literature, we hypothesize that younger, more educated farmers with less off-farm work will be more likely to adopt cover crops. Larger farms, and those with more labor, a greater percentage of owned land, more cropping diversity, cattle, and more area treated for weeds will be more likely to adopt. Crop insurance may increase or decrease adoption. Renewable energy production, as a proxy for pro-environmental attitudes, as well as adoption of other conservation practices and participation in federal programs, is expected to increase adoption. Adoption will be more likely in areas with longer growing seasons and more precipitation, as well as on farms that irrigate.

${ }^{3} \mathrm{~A}$ model including these systems, as well as ethanol and biodiesel, gave similar results. 


\section{Methods and data}

\subsection{Random utility theory and probit model}

Decision making for adoption of cover crops can be explained by random utility theory (Train, 2003). Farmers want to maximize their expected utility when they make a decision regarding adoption. However, there will be some factors that cannot be observed in the data. Thus, a farmer's expected utility as a function of cover crop adoption can be decomposed into $U_{i c}=V_{\mathrm{ic}}+\epsilon_{i c}$, where $V_{i c}$ is based on observable factors, $X_{i}$ and $\epsilon_{i c}$ which are unobserved or unobservable factors that affect can affect his or her utility and which are treated as random and assumed to have a normal distribution. The subscript $c$ denotes whether a farmer adopted cover crops or not (1: adopted; 0 otherwise). The probability of individual $i$ adopting cover crops can be written as follows:

$$
\begin{aligned}
\operatorname{Prob}(y=1 \mid X) & =\operatorname{Prob}\left(V_{i 1}+\varepsilon_{i 1}>V_{i 0}+\varepsilon_{i 0}\right) \\
& =\operatorname{Prob}\left(\varepsilon_{i 0}+\varepsilon_{i 1}<V_{i 0}-V_{i 1}\right) .
\end{aligned}
$$

We use a probit model to estimate the likelihood of adoption because of the dichotomous nature of the dependent variable. If a farmer adopts cover crops, then the independent variable is 1 ; otherwise (does not adopt) it is 0 . The probit regression is

$$
\mathrm{P}\left(y_{i}=1 \mid X_{i}\right)=\Phi\left(X_{i} \beta\right),
$$

where $\Phi(\cdot)$ is the cumulative normal distribution, $X_{i}=\left(x_{1}, \ldots, x_{k}\right)$ is a transposed vector including independent variables, and $\beta=\left(\beta_{1}, \ldots, \beta_{k}\right)^{\prime}$ is a vector of coefficients.

Additionally, we used clustered error terms to correct for spatial heterogeneity at the state level. Observations in the same state could be correlated because of similar policies and climatic conditions, but errors of individuals in other states are less likely to be correlated (Cameron and Miller, 2015). We can thus increase the efficiency of the estimates by using a clustered standard error term (Rogers, 1993; Wooldridge, 2010).

\subsection{ARMS data}

$\mathrm{ARMS}^{4}$ is a multiphase survey jointly conducted by the USDA Economic Research Service (ERS) and NASS. The survey is designed to be representative and to support key agricultural states. The survey consists of three phases. Phases 1 and 2 are conducted in the reference year, and phase 3 is conducted the following year. In phase 1, they screen farmers who produce the targeted commodity for that year's survey (e.g., corn, soybeans, wheat, cotton, etc.) during the summer. In phase 2, in the fall and winter, they conduct the field-level survey by choosing randomly from farmers identified in phase 1 about inputs, management practices, and costs for a specific field planted to the targeted crop. In phase 3, in the spring of the following year, they collect data at the whole-farm level about returns and costs, and household characteristics. The phase 3 sample is randomly selected from phase 1 and also those who finished phase 2 . Thus, the sample size of phase 3 is smaller than phase 2. Finally, the credibility of the gathered data is checked by ERS and NASS. In this study, the 2012 ARMS Soybean survey was used. A total of 2,472 and 1,871 observations were collected from 19 states in phases 2 and 3, respectively; however, only 1,712 observations were available for the analysis of cover crop adoption because of merging of the two phases and nonresponse to a few questions by some respondents.

The growing season data by stations within states for the previous 5 years were gathered from the High Plains Regional Climate Center (HPRCC, 2018). The growing season is defined as the number of days between first and last days equal to or above freezing. The yearly accumulated

\footnotetext{
${ }^{4}$ The following websites have additional information about ARMS (https://www.ers.usda.gov/data-products/armsfarm-financial-and-crop-production-practices/) and questionnaires (https://www.ers.usda.gov/data-products/armsfarm-financial-and-crop-production-practices/questionnaires-and-manuals/\#2012).
} 
precipitation data at the county level were from the National Oceanic and Atmospheric Administration (NOAA, 2018). Five-year (2008-2012) averages of growing season by state and precipitation by county were calculated.

\section{Results}

\subsection{Descriptive statistics}

Table 1 shows summary statistics for the ARMS data used in the regression., ${ }^{5,6}$ Approximately 17\% (288 of 1712 respondents) reported adopting cover crops on their farm. The average age was 56, and $56 \%$ of respondents had an education level more than or equal to a college degree. Twentyone percent of respondents had more than 100 days of off-farm work, which would imply they are probably not full-time farmers. The mean farm size was 1,780 acres, and on average, $39 \%$ of farmland was owned. The average number of hired laborers per farm was 0.17 . Respondents planted 2.55 field crops on average, and a third of farmers had cattle and calves. Seventy-seven percent of cropland or pasture ${ }^{7}$ was treated for weeds. Of the soybean fields that were the focus of the phase 2 survey, $12 \%$ of farmers reported it was classified as highly erodible land by NRCS. Most farmers, $85 \%$, were enrolled in federal crop insurance programs.

Adoption rates for conservation practices among soybean farmers were $22 \%$ for adoption of practices to reduce fertilizer use, ${ }^{8} 20 \%$ for a soil test, and $74 \%$ for no-till or conservation tillage. With respect to federal conservation programs, in 2012 these farmers on average received $\$ 1.58$ / acre (based on total farm acres) from EQIP or CSP contracts. As a proxy for general environmental attitudes, $2 \%$ of respondents had some type of renewable energy system.

Finally, the 5-year average of growing season was 175 days, and the 5-year mean precipitation was 39 inches, while $23 \%$ of farmers used irrigation on their farm.

\subsection{Probit regression results}

Table 2 shows the probit regression results ${ }^{9}$ for our preferred models (climate variable and state dummy models). The first model incorporates the 5-year average growing degree days for the farmer's state and the relevant county-level average precipitation for that time period. County-level growing degree days are not available (P.E. Guinan, Missouri State Climatologist, personal communication, November 2, 2018). This model allows us to directly examine the effect of climate on cover crop adoption. The second model includes a set of dummy variables for the states, which allows us to control for climate and characteristics such as cropping systems and policies (e.g., soil conservation subsidies). We include county-level precipitation in this model,

\footnotetext{
${ }^{5}$ ARMS restricts the publication of variable ranges.

${ }^{6}$ Because our dependent variable, cover crop adoption, was not the basis for weights in the ARMS data, and because our purpose was not to calculate acres under cover crops, we are using the unweighted data. We calculated the adoption rate using the soybean acreage weights and found it was similar, $17.4 \%$.

${ }^{7}$ The herbicide question does not allow us to separate cropland versus pasture, but according to the 2012 Census of Agriculture, these states have $27.6 \%$ of land in pasture overall and $55.7 \%$ in harvested cropland, with very little pasture in many of the major soybean states (e.g., $4.3 \%$ in Illinois and $8.1 \%$ in Iowa). Therefore, the majority of the herbicide was probably applied to cropland.

${ }^{8}$ Practices included (1) changing the type of commercial fertilizer, which is less anhydrous ammonia and more urea ammonium nitrate use; (2) soil test, split applications, variable rate applications, or soil incorporation; and (3) crop rotation.

${ }^{9}$ Prior to running our regression model, we examined correlation coefficients and the variance inflation factors (VIFs) for the explanatory variables. The correlation coefficients were smaller than 0.37 in absolute value for all variable pairs, except between precipitation and growing season, and squared size variables. The correlation between precipitation and growing season was 0.81 , but they are important factors for adoption of cover crops. We incorporate an interaction term in the regression. VIF values showed there was no evidence of multicollinearity because all variables had values less than 1.5 for the model with climate variables, and less than 10 for the model with county precipitation and state dummy variables (with Iowa as the base), except squared and interaction terms.
} 
Table 1. Summary statistics $(N=1712)$

\begin{tabular}{|c|c|c|}
\hline Variable Description & Mean & Standard Deviation \\
\hline Cover crop adoption (dependent variable; 1 : adopted; 0 : not) & 0.17 & 0.37 \\
\hline Age (years) & 56.00 & 11.58 \\
\hline Education (1: more than or equal to college; 0 : less than college) & 0.56 & 0.50 \\
\hline Operator off-farm days (1: more than 100 days; 0 : less than 100) & 0.21 & 0.41 \\
\hline Farm size ( 1,000 acres) & 1.78 & 2.15 \\
\hline The number of hired laborers (per farm) & 0.17 & 3.57 \\
\hline Owned land, \% (owned acres/owned plus rented acres) & 0.39 & 0.34 \\
\hline The number of field crops planted ${ }^{a}$ & 2.55 & 0.91 \\
\hline Cattle and calves ( 1 : yes; $0:$ no) & 0.33 & 0.47 \\
\hline Land treated for weeds, \% (crops or pasture, acres treated/total acres) & 0.77 & 0.30 \\
\hline Highly erodible soybean field (1: yes; 0 : no) & 0.12 & 0.33 \\
\hline Federal crop insurance (1: enrolled; 0 : not enrolled or unsure) & 0.85 & 0.36 \\
\hline Practices reducing fertilizer (1: used one or more practices; 0 : not) & 0.22 & 0.41 \\
\hline Soil test for 2012 (1: yes; 0: no) & 0.20 & 0.40 \\
\hline No-till/conservation tillage (1: yes; 0 : no) & 0.74 & 0.44 \\
\hline EQIP, CSP, CStP in 2012 (\$/acre) & 1.58 & 6.44 \\
\hline Renewable energy system (1: yes; $0:$ no) & 0.02 & 0.17 \\
\hline Growing season length (days) (c,e $^{c}$ & 175.18 & 33.50 \\
\hline Precipitation (inches) ${ }^{d}$ & 39.07 & 9.89 \\
\hline Irrigation (1: yes; 0: no) & 0.23 & 0.42 \\
\hline
\end{tabular}

Note: CSP or CStP, Conservation Stewardship Program; EQIP, Environmental Quality Incentives Program.

${ }^{a}$ Field crops were soybeans, corn, wheat, rice, peanuts, potatoes, and tobacco.

${ }^{\text {b} R e n e w a b l e ~ e n e r g y ~ s y s t e m s ~ w e r e ~ s o l a r ~ p a n e l s, ~ w i n d ~ t u r b i n e s, ~ a n d ~ g e o e x c h a n g e ~ a n d ~ s m a l l ~ h y d r o ~ s y s t e m s . ~}$

'State-level 5-year average.

${ }^{\mathrm{d} C}$ County-level 5-year average.

${ }^{\mathrm{e}}$ Growing season length was defined as days between the average last day (spring) and first day (fall) with a minimum temperature less than or equal to $32^{\circ} \mathrm{F}$.

but when we included state-level growing degree days it resulted in multicollinearity problems. The Akaike information criterion values were 1,318 and 1,255 , and the pseudo- $R^{2}$ values were 0.173 and 0.214 , respectively, which are quite reasonable for adoption models. Marginal effects were also calculated. ${ }^{10}$

The significant demographic factors in both models were that farmers having more than 100 days of off-farm work were less likely to adopt cover crops, consistent with McBride and Greene (2013) and Gedikoglu, McCann, and Artz (2011). Also, higher education was positively associated with cover crop use, as expected.

There were several significant results relating to farm characteristics. Farmers owning a higher percentage of their farmed land were more likely to adopt cover crops in the climate variable model, consistent with Bergtold et al. (2012). Ownership implies that farmers will be able to receive the long-term benefits of the practice.

\footnotetext{
${ }^{10}$ Marginal effects measure how much the probability of the dependent variable changes when a specific explanatory variable is increased by 1 unit under ceteris paribus conditions for other variables.
} 
Table 2. Results of probit regression and marginal effects for adoption of cover crops with robust standard errors

\begin{tabular}{|c|c|c|c|c|}
\hline \multirow[b]{2}{*}{ Variables } & \multicolumn{2}{|c|}{ Climate Variables } & \multicolumn{2}{|c|}{ State Dummy Variables } \\
\hline & Probit & $\begin{array}{l}\text { Marginal } \\
\text { Effects }\end{array}$ & Probit & $\begin{array}{l}\text { Marginal } \\
\text { Effects }\end{array}$ \\
\hline \multirow[t]{2}{*}{ Age (years) } & -0.006 & -0.001 & -0.006 & -0.001 \\
\hline & $(0.004)$ & $(0.001)$ & $(0.004)$ & $(0.001)$ \\
\hline \multirow{2}{*}{$\begin{array}{l}\text { Education (base: less than } \\
\text { college) }\end{array}$} & $0.128^{*}$ & $0.026^{*}$ & $0.195^{\star \star}$ & $0.038^{\star \star}$ \\
\hline & $(0.077)$ & $(0.016)$ & $(0.090)$ & $(0.018)$ \\
\hline \multirow{2}{*}{$\begin{array}{l}\text { Operator off-farm days (base: } \\
\text { less than 100) }\end{array}$} & $-0.302^{\star \star \star}$ & $-0.058^{\star \star *}$ & $-0.308^{\star \star \star}$ & $-0.057^{\star \star \star}$ \\
\hline & $(0.106)$ & $(0.020)$ & $(0.113)$ & $(0.019)$ \\
\hline \multirow[t]{2}{*}{ Farm size (1,000 acres) } & -0.005 & -0.004 & 0.012 & -0.002 \\
\hline & $(0.040)$ & $(0.007)$ & $(0.035)$ & $(0.006)$ \\
\hline \multirow[t]{2}{*}{ Square of farm size } & $-0.006^{\star \star \star}$ & & $-0.008^{\star \star \star}$ & \\
\hline & $(0.002)$ & & $(0.002)$ & \\
\hline \multirow{2}{*}{$\begin{array}{l}\text { The number of hired laborers } \\
\text { (per farm) }\end{array}$} & $2.811^{\star \star}$ & $0.609^{\star * \star}$ & $2.493^{\star \star}$ & $0.528^{\star \star}$ \\
\hline & (1.131) & $(0.216)$ & (1.157) & $(0.209)$ \\
\hline \multirow[t]{2}{*}{ Square of labor } & $-2.436^{\star \star \star}$ & & $-2.220^{\star \star \star}$ & \\
\hline & $(0.671)$ & & $(0.718)$ & \\
\hline \multirow[t]{2}{*}{ Farm size $\times$ labor } & $0.169^{\star \star \star}$ & & $0.195^{\star \star \star}$ & \\
\hline & $(0.050)$ & & $(0.050)$ & \\
\hline \multirow[t]{2}{*}{ Owned land (\% of farmed land) } & $0.268^{\star}$ & $0.056^{*}$ & 0.244 & 0.048 \\
\hline & (0.154) & $(0.032)$ & $(0.151)$ & $(0.029)$ \\
\hline \multirow[t]{2}{*}{ The number of field crops planted } & $0.313^{\star \star \star}$ & $0.065^{\star \star \star}$ & $0.296^{\star \star \star}$ & $0.059^{\star \star *}$ \\
\hline & $(0.051)$ & $(0.011)$ & $(0.054)$ & $(0.010)$ \\
\hline \multirow[t]{2}{*}{ Cattle (base: no) } & $0.222^{*}$ & $0.048^{*}$ & $0.223^{*}$ & $0.045^{\star}$ \\
\hline & $(0.113)$ & $(0.025)$ & $(0.121)$ & $(0.025)$ \\
\hline \multirow{2}{*}{$\begin{array}{l}\text { Land treated for weeds in crops or pasture } \\
\text { (\% of farmed land) }\end{array}$} & $-0.280^{\star}$ & $-0.058^{*}$ & -0.192 & -0.038 \\
\hline & $(0.161)$ & $(0.033)$ & $(0.182)$ & $(0.036)$ \\
\hline \multirow[t]{2}{*}{ Highly erodible soybean field (NRCS) } & -0.085 & -0.018 & -0.115 & -0.023 \\
\hline & $(0.168)$ & $(0.034)$ & $(0.177)$ & $(0.035)$ \\
\hline \multirow{2}{*}{$\begin{array}{l}\text { Federal crop insurance (base: not } \\
\text { enrolled/unsure) }\end{array}$} & 0.080 & 0.016 & 0.091 & 0.018 \\
\hline & $(0.082)$ & $(0.017)$ & $(0.093)$ & $(0.017)$ \\
\hline \multirow[t]{2}{*}{ Practices reducing fertilizer (base: no) } & $0.281^{\star \star}$ & $0.062^{\star \star}$ & $0.197^{\star \star}$ & $0.039^{\star \star}$ \\
\hline & $(0.112)$ & $(0.028)$ & $(0.086)$ & $(0.017)$ \\
\hline \multirow[t]{2}{*}{ Soil test (base: no) } & 0.162 & 0.035 & 0.076 & 0.015 \\
\hline & $(0.115)$ & $(0.026)$ & $(0.100)$ & $(0.020)$ \\
\hline \multirow[t]{2}{*}{ No-till/conservation tillage (base: no) } & $0.557^{\star \star \star}$ & $0.102^{\star \star \star}$ & $0.519^{\star \star \star}$ & $0.091^{\star \star \star}$ \\
\hline & $(0.107)$ & $(0.018)$ & $(0.114)$ & $(0.017)$ \\
\hline
\end{tabular}


Table 2. (Continued)

\begin{tabular}{|c|c|c|c|c|}
\hline \multirow[b]{2}{*}{ Variables } & \multicolumn{2}{|c|}{ Climate Variables } & \multicolumn{2}{|c|}{ State Dummy Variables } \\
\hline & Probit & $\begin{array}{l}\text { Marginal } \\
\text { Effects }\end{array}$ & Probit & $\begin{array}{l}\text { Marginal } \\
\text { Effects }\end{array}$ \\
\hline \multirow[t]{2}{*}{ EQIP, CSP, CStP in 2012 (\$/acre) } & $0.020^{\star \star \star}$ & $0.004^{\star * \star}$ & $0.021^{\star \star *}$ & $0.004^{\star \star \star}$ \\
\hline & $(0.006)$ & $(0.001)$ & $(0.006)$ & $(0.001)$ \\
\hline \multirow[t]{2}{*}{ Renewable energy system (base: no) } & $0.597^{\star \star \star}$ & $0.152^{\star \star}$ & $0.491^{\star \star}$ & $0.115^{\star}$ \\
\hline & $(0.225)$ & $(0.066)$ & $(0.241)$ & $(0.064)$ \\
\hline \multirow[t]{2}{*}{ Growing season length (days) } & 0.012 & $-0.002^{\star \star \star}$ & & \\
\hline & $(0.010)$ & $(0.001)$ & & \\
\hline \multirow[t]{2}{*}{ Precipitation (county level, inches) } & $0.134^{\star \star \star}$ & $0.008^{\star \star \star}$ & $0.018^{\star}$ & $0.004^{*}$ \\
\hline & $(0.038)$ & $(0.002)$ & $(0.009)$ & $(0.002)$ \\
\hline \multirow[t]{2}{*}{ Growing season $\times$ precipitation } & $-0.001^{\star \star \star}$ & & & \\
\hline & $(0.000)$ & & & \\
\hline \multirow[t]{2}{*}{ Irrigation (base: no) } & 0.165 & 0.036 & 0.220 & 0.046 \\
\hline & $(0.118)$ & $(0.026)$ & $(0.140)$ & $(0.030)$ \\
\hline \multirow[t]{2}{*}{ Arkansas (base: lowa) } & & & $-1.088^{\star \star \star}$ & $-0.215^{\star \star \star}$ \\
\hline & & & $(0.232)$ & $(0.044)$ \\
\hline \multirow[t]{2}{*}{ Illinois } & & & $-0.200^{\star \star}$ & $-0.040^{\star \star}$ \\
\hline & & & $(0.079)$ & $(0.015)$ \\
\hline \multirow[t]{2}{*}{ Indiana } & & & $0.185^{*}$ & $0.037^{*}$ \\
\hline & & & $(0.111)$ & $(0.022)$ \\
\hline \multirow[t]{2}{*}{ Kansas } & & & $-0.362^{\star \star \star}$ & $-0.072^{\star \star \star}$ \\
\hline & & & $(0.086)$ & $(0.017)$ \\
\hline \multirow[t]{2}{*}{ Kentucky } & & & $0.719^{\star \star \star}$ & $0.142^{\star \star \star}$ \\
\hline & & & $(0.154)$ & $(0.032)$ \\
\hline \multirow[t]{2}{*}{ Louisiana } & & & $-1.540^{\star \star \star}$ & $-0.304^{\star \star \star}$ \\
\hline & & & $(0.232)$ & $(0.044)$ \\
\hline \multirow[t]{2}{*}{ Michigan } & & & $0.234^{\star \star \star}$ & $0.046^{\star \star \star}$ \\
\hline & & & $(0.080)$ & $(0.016)$ \\
\hline \multirow[t]{2}{*}{ Minnesota } & & & $0.265^{\star \star \star}$ & $0.052^{\star \star \star}$ \\
\hline & & & $(0.082)$ & $(0.016)$ \\
\hline \multirow[t]{2}{*}{ Mississippi } & & & $-1.280^{\star \star \star}$ & $-0.253^{\star \star \star}$ \\
\hline & & & $(0.221)$ & $(0.042)$ \\
\hline \multirow[t]{2}{*}{ Missouri } & & & 0.049 & 0.010 \\
\hline & & & $(0.110)$ & $(0.022)$ \\
\hline \multirow[t]{2}{*}{ Nebraska } & & & 0.001 & 0.000 \\
\hline & & & $(0.112)$ & $(0.022)$ \\
\hline North Carolina & & & $-0.293^{\star}$ & $-0.058^{\star}$ \\
\hline
\end{tabular}


Table 2. (Continued)

\begin{tabular}{|c|c|c|c|c|}
\hline \multirow[b]{2}{*}{ Variables } & \multicolumn{2}{|c|}{ Climate Variables } & \multicolumn{2}{|c|}{ State Dummy Variables } \\
\hline & Probit & $\begin{array}{l}\text { Marginal } \\
\text { Effects }\end{array}$ & Probit & $\begin{array}{l}\text { Marginal } \\
\text { Effects }\end{array}$ \\
\hline & & & $(0.161)$ & $(0.031)$ \\
\hline \multirow[t]{2}{*}{ North Dakota } & & & $-0.408^{\star \star}$ & $-0.081^{\star \star}$ \\
\hline & & & $(0.162)$ & $(0.032)$ \\
\hline \multirow[t]{2}{*}{ Ohio } & & & -0.043 & -0.008 \\
\hline & & & $(0.074)$ & $(0.015)$ \\
\hline \multirow[t]{2}{*}{ South Dakota } & & & $-0.343^{\star \star \star}$ & $-0.068^{\star \star \star}$ \\
\hline & & & $(0.103)$ & $(0.020)$ \\
\hline \multirow[t]{2}{*}{ Tennessee } & & & -0.112 & -0.022 \\
\hline & & & $(0.182)$ & $(0.036)$ \\
\hline \multirow[t]{2}{*}{ Virginia } & & & $1.023^{\star \star \star}$ & $0.202^{\star \star \star}$ \\
\hline & & & $(0.129)$ & $(0.027)$ \\
\hline \multirow[t]{2}{*}{ Wisconsin } & & & $0.262^{\star \star \star}$ & $0.052^{\star \star \star}$ \\
\hline & & & $(0.069)$ & $(0.014)$ \\
\hline \multirow[t]{2}{*}{ Constant } & $-5.682^{\star \star \star}$ & & $-2.915^{\star \star \star}$ & \\
\hline & $(1.707)$ & & $(0.396)$ & \\
\hline Observations & \multicolumn{4}{|c|}{1,712} \\
\hline Pseudo- $R^{2}$ & 0.173 & & 0.214 & \\
\hline Akaike information criterion & 1318 & & 1255 & \\
\hline
\end{tabular}

Notes: Robust standard errors in parentheses. ${ }^{\star \star \star} P<0.01$; ${ }^{\star \star} P<0.05$; ${ }^{\star} P<0.1$. CSP or CStP, Conservation Stewardship Program; EQIP, Environmental Quality Incentives Program; NRCS, Natural Resources Conservation Service.

Although farm size was not significant, the squared term was; very large farms seem somewhat less likely to adopt cover crops. Farmers who hired more laborers were more likely to adopt cover crops, but the negative squared term indicates this effect was diminishing. ${ }^{11}$ The interaction term between farm size and labor was also significant. Together with the finding regarding off-farm work, this implies that labor costs and labor availability could be an important issue for adoption of cover crops. Additionally, marginal effects (which incorporates the squared and interaction terms) showed hired labor was the most important factor for adoption of cover crops. In both models, if farmers hire 1 more unit of labor, the likelihood of adoption of cover crops would increase by more than 50 percentage points. More labor availability would reduce the time constraints farmers face with cover crops, especially during the busy planting and harvest seasons.

In both models, farmers who plant a greater variety of field crops ${ }^{12}$ and have cattle were more likely to use cover crops, consistent with Arbuckle and Roesch-McNally (2015) and Singer, Nusser, and Alf (2007). As we indicated earlier, diverse cropping systems may imply availability of appropriate equipment for cover crops, as well as knowledge of a broader range of crops. Farms with ruminants have additional benefits from using cover crops (i.e., forage). The result regarding the percentage of cropland or pasture treated for weeds was contrary to our expectations in the

\footnotetext{
${ }^{11}$ Our examination of the data shows that farms with very large numbers of laborers tended to have livestock, such as dairy.

${ }^{12} \mathrm{We}$ included crop rotation versus continuous soybeans in one model, but the data were for a specific soybean field, not for the farm, and the effect was not significant.
} 


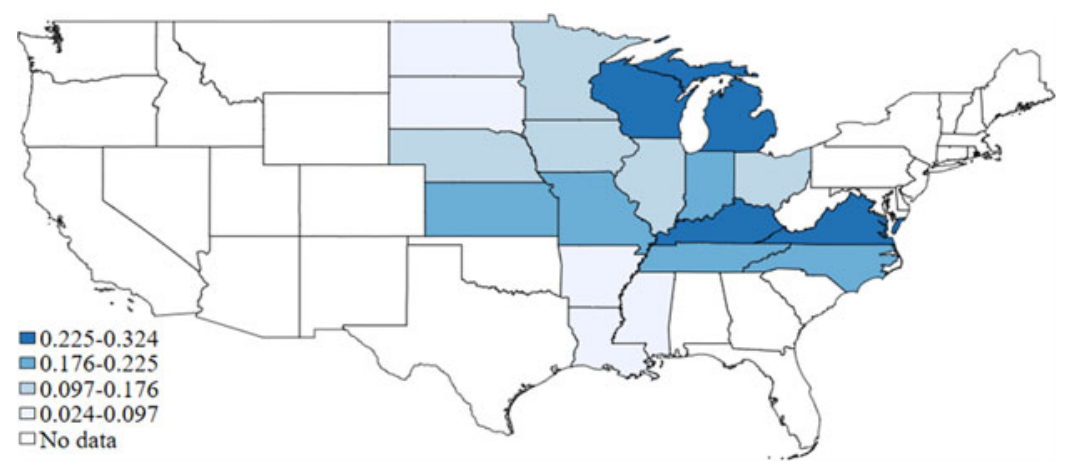

Figure 1. State-level maps with predicted probabilities (model: climate variables).

climate variable model (and insignificant in the state dummy model). One potential explanation is that, according to a recent cover crop survey, farmers who have not used cover crops were afraid that cover crops would become weeds (CTIC, 2017). It is also the case that the agronomic studies focus on the weed inhibiting effects of cover crops before cash crops, but the herbicide variable in the ARMS data does not allow us to examine that land use separately from pasture.

As expected, we also found that cover crop adoption was positively related to other best management practices for water quality including reduced fertilizer use and conservation tillage/ no-till. Cover crops thus seem to be viewed as complements to, rather than substitutes for, these practices. Farmers using cover crops perceived that the practice could help reduce inputs, including fertilizer (CTIC, 2017). Those who have received more federal EQIP or CSP payments were more likely to adopt the practice, consistent with Arbuckle and Roesch-McNally (2015) and Singer, Nusser, and Alf (2007). Cover crops are one of the practices supported by these programs, and economic theory predicts that subsidizing practices will increase adoption.

Farmers having renewable energy systems were more likely to adopt, as expected. Use of these technologies is likely related to farmers' general environmental awareness and attitudes. Renewable energy had a very low adoption rate (2\%) in our data, and these farmers can thus be defined as early adopters of those technologies according to Rogers (2003). Early adopters of environmentally friendly technologies, such as solar energy (Haas et al., 1999) and electric vehicles (Curtin, Shrago, and Mikkelsen, 2009; Plotz et al., 2014), tend to have stronger environmental preferences. In addition, marginal effects showed that having a renewable energy system was the second most important factor for adoption of cover crops; it increased the probability of using cover crops by more than 11 percentage points. Given the previous results for practices that improve soil health and water quality, and which may themselves indicate conservation attitudes, this result is notable.

In both models, farmers in counties with more precipitation were more likely to use cover crops, but the interaction term in the climate variable model between growing season ${ }^{13}$ and precipitation implies that the probability was decreasing as each factor was increasing. The rate of decrease was relatively smaller for precipitation than growing season because of the scale of the respective coefficients as we can see in the marginal effect of growing season length. Although the effect of precipitation was small, it does support the discussion of climatic constraints to cover crop use in the literature. Favorable growing conditions are needed for establishment of cover

\footnotetext{
${ }^{13}$ In an earlier model, we included temperature instead of growing season, but growing season is a more general variable to represent conditions for plant growth over the season, and also temperature was more highly correlated with precipitation than was growing season.
} 


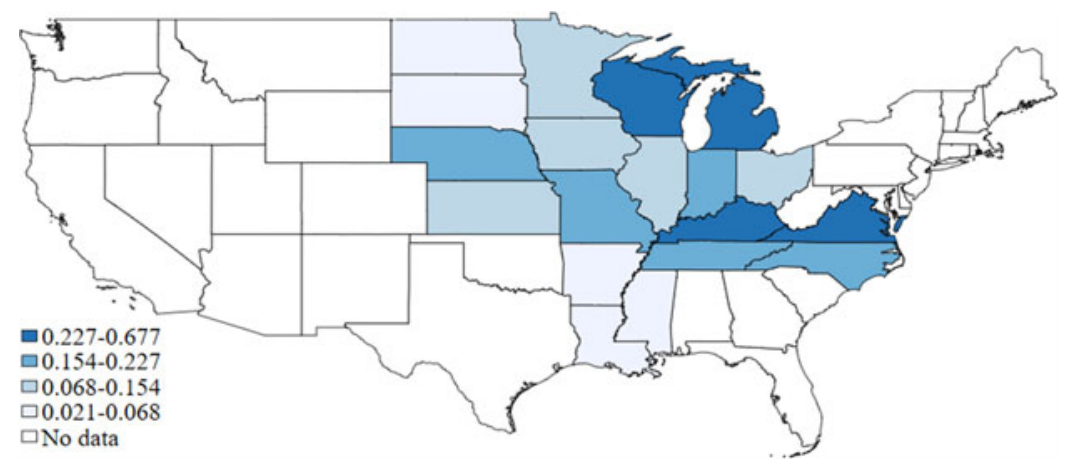

Figure 2. State-level maps with predicted probabilities (model: states dummies).

crops after harvest, and cover crops could reduce water availability for the next cash crop if terminated too late in dry regions (Unger and Vigil, 1998).

The state dummy variables control for a variety of factors in addition to those in our model. As indicated earlier, we were not able to include state-level growing season data in our state dummy model. The state dummies may also incorporate factors such as topography. Iowa is fairly centrally located and is a major agricultural state and is therefore used as the base. States less likely than Iowa to have farmers who have adopted cover crops, ceteris paribus, include Arkansas, Illinois, Kansas, Louisiana, Mississippi, North Carolina, North Dakota, and South Dakota. Of these, the marginal effect was greatest for Louisiana. States more likely than Iowa to adopt include Indiana, Kentucky, Michigan, Minnesota, Virginia, and Wisconsin. Of these, the marginal effect was greatest for Virginia. In order to visualize the results, Figures 1 and 2 show the predicted probabilities of adoption by state for the two models. Cold, dry states such as North and South Dakota have a lower probability of adopting cover crops, as expected. On the other hand, warm, wet states in the Mississippi Delta are also less likely to adopt. One possible explanation is that this climate enables double-cropping (Borchers, Truex-Powell, and Nickerson, 2014), making cover crops less advantageous. The ARMS data show that in 2011 Louisiana, Arkansas, and Mississippi had double-cropping rates of $20 \%, 13 \%$, and $9 \%$, respectively. This result may also be related to the growing season results in the climate model. In areas with a long growing season and sufficient precipitation, it may be feasible and more profitable to have a second cash crop, rather than planting cover crops.

\section{Conclusion}

Reducing nonpoint-source pollution from agriculture into water resources is important. Cover crops can be a solution that not only reduces nonpoint-source pollutants but also improves soil health and provides other benefits, which can have positive effects on yields of cash crops. Thus, cover crops can be a win-win practice for farmers as well as the environment. Our results provide evidence that there are a number of barriers to adoption that vary with climate and farming system.

The adoption rate of cover crops is still low, especially in regions with a short growing season, because of the small window for seeding cover crops after harvest of cash crops. In addition, most farmers plant cover crops after harvest of their cash crops, which is one of the busiest times for farmers. In this situation, farmers may not be able to seed cover crops because of limited labor/ time. Nevertheless, some states such as Michigan have higher adoption rates, so shorter growing seasons may be overcome. Researchers have been working on cover crop interseeding to enable planting of cover crops before harvest (Wells et al., 2016). However if farmers seed cover crops too early, it could cause cash crop yield reductions because of competition for nutrients or water 
before harvest (Uchino et al., 2009). Our results also highlight the small but significant effect of higher precipitation, using county-level data. Management of cover crops in dry regions is complex because if not terminated early enough, the cover crops may compete for moisture; however, the mulch created by cover crops can reduce water evaporation (Kaye and Quemada, 2017). Another interesting finding is that some areas that would seem to have favorable conditions for cover crops actually have lower adoption rates. We think this may be because of the potential for double-cropping.

According to our results, availability of appropriate equipment for seeding cash crops, for interseeding, and for planting cash crops into cover crop residue is important. Farmers who already have diverse cropping systems and who practice conservation tillage may already have the necessary equipment. Although the effect was fairly small, participation in cost-share programs such as EQIP and CSP was associated with higher probability of adoption. Additional economic incentives may thus increase adoption rates.

However, the most important finding regarding barriers to cover crop use is the effect of the additional labor and management requirements during busy times of the year. This finding suggests that the development of less complicated and less time-consuming technologies may contribute to greater cover crop adoption. A more general implication of our research is that there is a need to consider how to create recommended cover crop approaches that take account of both differing climates and differing farming systems.

Our findings suggest some interesting future research. It would be helpful to carefully study the effect of farming systems on cover crop adoption. The farming system will affect the costs and benefits from cover crops. For instance, corn needs a longer growing season than soybeans. This affects the window in which cover crops can be planted and thus may affect farmers' adoption of cover crops. Ruminants can benefit from forage production, but this may be more relevant for cow-calf operations. More generally, compatibility with the current farming system, including issues such as rotations and double-cropping, needs to be examined. A long-term longitudinal study could examine whether changing climatic conditions, which would increase the on-farm benefits of cover crops, would affect adoption of this practice. Complementary research to this study would examine the effect of cover crops on yields and profits under different climatic conditions and in different farming systems.

Acknowledgments. The research was partially supported by the USDA National Integrated Water Quality Grant Program number 110.C (Award 2012-03652), and by the USDA Multi-state Grant W-3190 Management and Policy Challenges in a Water-Scarce World, as well as the Missouri Agricultural Experiment Station. We appreciate the support of Mr. Brad Parks at the USDA-NASS data lab in St. Louis, Missouri.

Conflict of interest. None.

\section{References}

Alonso-Ayuso, M., J.L. Gabriel, and M. Quemada. “The Kill Date as a Management Tool for Cover Cropping Success.” PLoS ONE 9, 10(2014):e109587.

Arbuckle, J.G., and G. Roesch-McNally. "Cover Crop Adoption in Iowa: The Role of Perceived Practice Characteristics." Journal of Soil and Water Conservation 70, 6(2015):418-29.

Balkcom, K.S., L.M. Duzy, T.S. Kornecki, and A.J. Price. "Timing of Cover Crop Termination: Management Considerations for the Southeast." Crop, Forage \& Turfgrass Management 1, 1(2015):1-7.

Beckman, J., and I.M. Xiarchos. "Why Are Californian Farmers Adopting More (and Larger) Renewable Energy Operations?” Renewable Energy 55(July 2013):322-30.

Bergtold, J.S., P.A. Duffy, D. Hite, and R.L. Raper. "Demographic and Management Factors Affecting the Perceived Benefit of Winter Cover Crops in the Southeast." Journal of Agricultural and Applied Economics 44, 1(2012):99-116.

Bergtold, J.S., S. Ramsey, L. Maddy, and J.R. Williams. "A Review of Economic Considerations for Cover Crops as a Conservation Practice." Renewable Agriculture and Food Systems 34, 1(2017):62-76.

Borchers, A., E. Truex-Powell, and C. Nickerson. Multi-Cropping Practices: Recent Trends in Double Cropping. Washington, DC: U.S. Department of Agriculture, Economic Research Service, Economic Information Bulletin No. 125, 2014.

Cameron, A.C. and D.L. Miller. “A Practitioner 's Guide to Cluster-Robust Inference." Journal of Human Resources 50, 2(2015):317-72. 
Cameron, K.C., H.J. Di, and J.L. Moir. "Nitrogen Losses from the Soil/Plant System: A Review." Annals of Applied Biology 162, 2(2013):145-73.

Carpenter, S.R. "Eutrophication of Aquatic Ecosystems: Bistability and Soil Phosphorus." Proceedings of the National Academy of Sciences of the United States of America 102, 29(2005):10002-5.

Castellano, M.J., M.J. Helmers, J.E. Sawyer, D.W. Barker, and L. Christianson. "Nitrogen, Carbon, and Phosphorus Balances in Iowa Cropping Systems: Sustaining the Soil Resource." Proceedings of the 24th Integrated Crop Management Conference. Ames: Iowa State University Digital Repository, 2012. pp. 145-56. Internet site: https://lib.dr. iastate.edu/cgi/viewcontent.cgi?article=1111\&context=icm (Accessed June 6, 2019).

Chen, G., and R.R. Weil. "Penetration of Cover Crop Roots through Compacted Soils." Plant and Soil 331, 1(2010):31-43.

Chen, G., and R.R. Weil. "Root Growth and Yield of Maize as Affected by Soil Compaction and Cover Crops." Soil and Tillage Research 117(December 2011):17-27.

Chen, K.K. "Assessing the Effects of Customer Innovativeness, Environmental Value and Ecological Lifestyles on Residential Solar Power Systems Install Intention.” Energy Policy 67(April 2014):951-61.

Conservation Technology Information Center (CTIC). Report of the 2015-16 National Cover Crop Survey. West Lafayette, IN: Joint publication of the Conservation Technology Information Center, the North Central Region Sustainable Agriculture Research and Education Program, and the American Seed Trade Association, 2016.

Conservation Technology Information Center (CTIC). Report of the 2016-17 National Cover Crop Survey. West Lafayette, IN: Conservation Technology Information Center, the North Central Region Sustainable Agriculture Research and Education Program, and the American Seed Trade Association, 2017.

Curell, C. "Using Cover Crops to Decrease Irrigation Costs.” Michigan State University Extension, 2012. Internet site: https:// www.canr.msu.edu/news/using_cover_crops_to_decrease_irrigation_costs (May 29, 2019).

Curtin, R., Y. Shrago, and J. Mikkelsen. Plug-in Hybrid Electric Vehicles. University of Michigan, 2009. Internet site: http:// ns.umich.edu/Releases/2009/Oct09/PHEV_Curtin.pdf (Accessed June 6, 2019).

Davidson, E.A., M. Keller, H.E. Erickson, L.V. Verchot, and E. Veldkamp. “Testing a Conceptual Model of Soil Emissions of Nitrous and Nitric Oxides." BioScience 50, 8(2000):667-80.

Devlin, D.L., K. Losses, G.M. Pierzynski, and K. Janssen. Best Management Practices for Phosphorus. Manhattan: Agricultural Experiment Station and Cooperative Extension Service, Kansas State University, 2002.

Dinnes, D.L., D.L. Karlen, D.B. Jaynes, T.C. Kaspar, J.L. Hatfield, T.S. Colvin, and C.A. Cambardella. "Nitrogen Management Strategies to Reduce Nitrate Leaching in Tile-Drained Midwestern Soils." Agronomy Journal 94, 1(2002):153-71.

Dunn, M., J.D. Ulrich-Schad, L.S. Prokopy, R.L. Myers, C.R. Watts, and K. Scanlon. "Perceptions and Use of Cover Crops among Early Adopters: Findings from a National Survey." Journal of Soil and Water Conservation 71, 1(2016):29-40.

Feather, P., and G. Amacher. "Role of Information in the Adoption of Best Management Practices for Water Quality Improvement." Agricultural Economics 11, 2-3(1994):159-70.

Forcella, F. "Short- and Full-Season Soybean in Stale Seedbeds versus Rolled-Crimped Winter Rye Mulch." Renewable Agriculture and Food Systems 29, 1(2014):92-99.

Gebhardt, M.R., T.C. Daniel, E.E. Schweizer, and R.R. Allmaras. “Conservation Tillage.” Science 230, 4726(1985):625-30.

Gedikoglu, H., L. McCann, and G. Artz. "Off-Farm Employment Effects on Adoption of Nutrient Management Practices." Agricultural and Resource Economics Review 40, 2(2011):293-306.

Grisso, R., D. Holshouser, and R. Pitman. Equipment Considerations for No-till Soybean Seeding. Virginia Cooperative Extension, 2009. Internet site: https:/vtechworks.lib.vt.edu/bitstream/handle/10919/56801/442-456.pdf?sequence=1 (Accessed June 6, 2019).

Haas, R., M. Ornetzeder, K. Hametner, A. Wroblewski, and M. Hubner. "Socio-Economic Aspect of the Austrian $200 \mathrm{KWp}$ Photovoltaic Rooftop Programme." Solar Energy 66, 3(1999):183-91.

Hertwig, R., G. Barron, E.U. Weber, and I. Erev. "Decisions from Experience and the Effect of Rare Events in Risky Choice." Psychological Science 15, 8(2004):534-39.

High Plains Regional Climate Center (HPRCC). "Frost/Freeze Summaries.” Internet site: http://climod.unl.edu/ (Accessed May 31, 2018).

Hoorman, J.J. Using Cover Crops to Improve Soil and Water Quality. Fact Sheet, Agriculture and Natural Resources. The Ohio State University Extension, 2009. Internet site: file:///C:/Users/hfb/Downloads/Using_Cover_crops_to_improve_ Soil_and_Water_.pdf (Accessed May 29, 2019).

Johnson, C., G. Albrecht, Q. Ketterings, J. Beckman, and K. Stockin. Nitrogen Basics - The Nitrogen Cycle. Agronomy Fact Sheet 2. Cornell University Cooperative Extension, 2005. Internet site: http://cceonondaga.org/resources/nitrogen-basicsthe-nitrogen-cycle (Accessed May 29, 2019).

Kaspar, T.C., and J.W. Singer. “The Use of Cover Crops to Manage Soil.” Soil Management: Building a Stable Base for Agriculture. J.L. Hatfield and T.J. Sauer, eds. Madison, WI: American Society of Agronomy and Soil Science of America, 2011, pp. 321-38. 
Kaufmanna, R.K., M.L. Mannb, S. Gopala, J.A. Liedermanc, P.D. Howed, F. Pretise, X. Tanga, and M. Gilmore. "Spatial Heterogeneity of Climate Change as an Experiential Basis for Skepticism." Proceedings of the National Academy of Sciences of the United States of America 114, 1(2017):67-71.

Kaye, J.P., and M. Quemada. "Using Cover Crops to Mitigate and Adapt to Climate Change: A Review." Agronomy for Sustainable Development 37(2017):4.

Lal, R. "Soil Carbon Sequestration to Mitigate Climate Change." Geoderma 123, 1-2(2004):1-22.

Lal, R., D.C. Reicosky, and J.D. Hanson. "Evolution of the Plow over 10,000 Years and the Rationale for No-Till Farming." Soil and Tillage Research 93, 1(2007):1-12.

Laloy, E., and C.L. Bielders. "Effect of Intercropping Period Management on Runoff and Erosion in a Maize Cropping System." Journal of Environment Quality 39, 3(2010):1001-8.

Langdale, G.W., R.A. Leonard, and A.W. Thomas. "Conservation Practice Effects on Phosphorus Losses from Southern Piedmont Watersheds." Journal of Soil and Water Conservation 40, 1(1985):157-61.

Lazarus, W., and A. Keller. Economic Analysis of Cover Crops on Farms Participating in the Southeastern Minnesota Cover Crop and Soil Health Initiative. University of Minnesota Extension, 2018. Internet site: https://www.lccmr.leg.mn/projects/ 2015/finals/2015_04e_UMN_Economics_CoverCrop.pdf (Accessed May 29, 2019).

Li, Y., E.J. Johnson, and L. Zaval. "Local Warming: Daily Temperature Change Influences Belief in Global Warming." Psychological Science 22, 4(2011):454-59.

Lu, H., R.B. Bryant, A.R. Buda, A.S. Collick, G.J. Folmar, and P.J.A. Kleinman. "Long-Term Trends in Climate and Hydrology in an Agricultural, Headwater Watershed of Central Pennsylvania, USA." Journal of Hydrology: Regional Studies 4B(September 2015):713-31.

Lu, Y.-C., K.B. Watkins, J.R. Teasdale, and A.A. Abdul-Baki. “Cover Crops in Sustainable Food Production.” Food Reviews International 16, 2(2000):121-57.

Marzen, C.G., and J.G. Ballard. "Climate Change and Federal Crop Insurance." Environmental Affairs Law Review 43, 2(2016):387-410.

Mbuthia, L.W., V. Acosta-Martínez, J. DeBruyn, S. Schaeffer, D. Tyler, E. Odoi, M. Mpheshea, F. Walker, and N. Eash. "Long Term Tillage, Cover Crop, and Fertilization Effects on Microbial Community Structure, Activity: Implications for Soil Quality.” Soil Biology \& Biochemistry 89(October 2015):24-34.

McBride, W.D., and S.G. Daberkow. "Information and the Adoption of Precision Farming Technologies." Journal of Agribusiness 21, 1(2003):21-38.

McBride, W.D., and C.R. Greene. "Organic Data and Research from the ARMS Survey: Findings on Competitiveness of the Organic Soybean Sector.” Crop Management 12, 1(2013):1-11.

Midwest Cover Crops Council. Integrating Cover Crops in Soybean Rotations: Challenges and Recommendations for the North Central Region. Midwest Cover Crops Council, 2015. Internet site: http://www.soybeanresearchinfo.com/Integrating CoverCrops_Soybeans2015.pdf (Accessed May 29, 2019).

Mirsky, S.B., M.R. Ryan, J.R. Teasdale, W.S. Curran, C.S. Reberg-Horton, J.T. Spargo, M.S. Wells, C.L. Keene, and J.W. Moyer. "Overcoming Weed Management Challenges in Cover Crop-Based Organic Rotational No-Till Soybean Production in the Eastern United States." Weed Technology 27, 1(2013):193-203.

Myers, R., and C. Watts. "Progress and Perspectives with Cover Crops: Interpreting Three Years of Farmer Surveys on Cover Crops." Journal of Soil and Water Conservation 70, 6(2015):125A-29A.

National Oceanic and Atmospheric Administration (NOAA). “Climate at a Glance: Statewide Time Series." Internet site: https://www.ncdc.noaa.gov/cag/statewide/time-series (Accessed May 31, 2018).

Plotz, P., U. Schneider, J. Globisch, and E. Dutschke. "Who Will Buy Electric Vehicles? Identifying Early Adopters in Germany." Transportation Research Part A: Policy and Practice 67(September 2014):96-109.

Prokopy, L.S., K. Floress, D. Klotthor-Weinkauf, and A. Baumgart-Getz. "Determinants of Agricultural Best Management Practice Adoption: Evidence from the Literature." Journal of Soil and Water Conservation 63, 5(2008):300-311.

Reeves, D.W. “Cover Crops and Rotations.” Crops Residue Management: Advances in Soil Science. J.L. Hatfield and B.A. Stewart, eds. Boca Raton, FL: Lewis, 1994, pp. 125-72.

Ribaudo, M., J. Delgado, L. Hansen, M. Livingston, R. Mosheim, and J. Williamson. Nitrogen in Agricultural Systems: Implications for Conservation Policy. Washington, DC: U.S. Department of Agriculture, Economic Research Service, Economic Research Report No. 127, 2011.

Rogers, E.M. Diffusion of Innovations. 5th ed. New York: Free Press, 2003.

Rogers, W. "Regression Standard Errors in Clustered Samples." Stata Technical Bulletin 13(1993):19-23.

Sarrantonio, M., and E. Gallandt. "The Role of Cover Crops in North American Cropping Systems." Journal of Crop Production 8, 1-2(2003):53-74.

Schimmelpfennig, D., and R. Ebel. "Sequential Adoption and Cost Savings from Precision Agriculture." Journal of Agricultural and Resource Economics 41, 1(2016):97-115.

Sharpley, A.N., and S.J. Smith. "Effects of Cover Crops on Surface Water Quality Nutrient Transport." Cover Crops for Clean Water. W.L. Hargrove, ed. Ankeny, IA: Soil and Water Conservation Society, 1991, pp. 41-49. 
Singer, J.W., S.M. Nusser, and C.J. Alf. “Are Cover Crops Being Used in the US Corn Belt?” Journal of Soil and Water Conservation 62, 5(2007):353-58.

Soule, M.J., A. Tegene, and K.D. Wiebe. "Land Tenure and the Adoption of Conservation Practices." American Journal of Agricultural Economics 82, 4(2000):993-1005.

Steenwerth, K., and K.M. Belina. "Cover Crops Enhance Soil Organic Matter, Carbon Dynamics and Microbiological Function in a Vineyard Agroecosystem.” Applied Soil Ecology 40, 2(2008):359-69.

Strock, J.S., P.M. Porter, and M.P. Russelle. "Cover Cropping to Reduce Nitrate Loss through Subsurface Drainage in the Northern U.S. Corn Belt.” Journal of Environment Quality 33, 3(2004):1010-16.

Tonitto, C., M.B. David, and L.E. Drinkwater. "Replacing Bare Fallows with Cover Crops in Fertilizer-Intensive Cropping Systems: A Meta-Analysis of Crop Yield and N Dynamics.” Agriculture, Ecosystems and Environment 112, 1(2006):58-72.

Train, K.E. Discrete Choice Methods with Simulation. Cambridge: Cambridge University Press, 2003.

Uchino, H., K. Iwama, Y. Jitsuyama, T. Yudate, and S. Nakamura. "Yield Losses of Soybean and Maize by Competition with Interseeded Cover Crops and Weeds in Organic-Based Cropping Systems." Field Crops Research 113, 3(2009):342-51.

Unger, P.W., and M.F. Vigil. "Cover Crop Effects on Soil Water Relationships." Journal of Soil and Water Conservation 53, 3(1998):200-207.

U.S. Department of Agriculture, National Agricultural Statistics Service (USDA-NASS). 2007 Census of Agriculture: OnFarm Renewable Energy Production Survey (2009). Washington, DC: USDS-NASS, 2011. Internet site: https://www.nass. usda.gov/Publications/AgCensus/2007/Online_Highlights/On-Farm_Energy_Production/energy09.pdf (Accessed May 29, 2019).

U.S. Department of Agriculture, National Agricultural Statistics Service (USDA-NASS). 2017 Census of Agriculture: United States Summary and State Data. Washington, DC: USDA-NASS, 2019. Internet site: https://www.nass.usda.gov/ Publications/AgCensus/2017/Full_Report/Volume_1,_Chapter_1_US/usv1.pdf (Accessed May 29, 2019).

U.S. Department of Agriculture, Natural Resources Conservation Service (USDA-NRCS). “Conservation Choices: Cover Crops.” Internet site: https://www.nrcs.usda.gov/wps/portal/nrcs/detail/null/?cid=nrcseprd414410 (Accessed August 10, 2018).

U.S. Environmental Protection Agency (EPA). Protecting Water Quality from Agricultural Runoff. Washington, DC: EPA, Nonpoint Source Control Branch, 2005.

U.S. Environmental Protection Agency (EPA). Climate Change Indicators in the United States: Length of Growing Season. Washington, DC: EPA, 2016. Internet site: https://www.epa.gov/sites/production/files/2016-08/documents/print_growingseason-2016.pdf (Accessed May 29, 2019).

Wallace, J., A. Williams, J. Liebert, V. Ackroyd, R. Vann, W. Curran, C. Keene, M. VanGessel, M. Ryan, and S. Mirsky. "Cover Crop-Based, Organic Rotational No-Till Corn and Soybean Production Systems in the Mid-Atlantic United States." Agriculture 7, 4(2017):34.

Ward, A., A. Sharpley, K. Miller, W. Dick, J. Hoorman, J. Fulton, and G.A. LaBarge. “An Assessment of In-Field Nutrient Best Management Practices for Agricultural Crop Systems with Subsurface Drainage.” Journal of Soil and Water Conservation 73, 1(2018):5A-10A.

Weber, C., and L. McCann. “Adoption of Nitrogen-Efficient Technologies by U.S. Corn Farmers.” Journal of Environment Quality 44, 2(2015):391-401.

Wells, M.S., A. Hard, E. Ristau, and D. Nicolai. Soil Management and Health Early Season Cover Crop Interseeding in Corn. St. Paul: University of Minnesota Extension, 2016.

Williamson, J.M. "The Role of Information and Prices in the Nitrogen Fertilizer Management Decision: New Evidence from the Agricultural Resource Management Survey." Journal of Agricultural and Resource Economics 36, 3(2011):552-72.

Wittwer, R.A., B. Dorn, W. Jossi, and M.G.A. Van Der Heijden. "Cover Crops Support Ecological Intensification of Arable Cropping Systems.” Scientific Reports 7(February 2017):1-12.

Wooldridge, J.M. Econometric Analysis of Cross Section and Panel Data. Cambridge, MA: MIT Press, 2010.

Yoo, K.H., J.T. Touchton, and R.H. Walker. "Runoff, Sediment and Nutrient Losses from Various Tillage Systems of Cotton." Soil and Tillage Research 12, 1(1988):13-24.

Zhang, T.Q., C.S. Tan, Z.M. Zheng, T. Welacky, and Y.T. Wang. "Drainage Water Management Combined with Cover Crop Enhances Reduction of Soil Phosphorus Loss.” Science of the Total Environment 586(May 2017):362-71.

Cite this article: Lee S and McCann L (2019). Adoption of Cover Crops by U.S. Soybean Producers. Journal of Agricultural and Applied Economics 51, 527-544. https://doi.org/10.1017/aae.2019.20 